\title{
Personality traits predicting different aspects of subjective well-being in elderly adults
}

\author{
Mojca Petrič ${ }^{1,2^{*}}$ and Maja Zupančič \\ ${ }^{1}$ Department of Psychology, Faculty of Arts, University of Ljubljana, Slovenia \\ ${ }^{2}$ Department of Psychotherapy, Psychiatric Hospital Begunje, Slovenia
}

\begin{abstract}
The study examined unique predictive relations of personality traits with three components of subjective well-being (WB) in a normative sample $(N=272 ; 70 \%$ females) of Slovene elderly $(M=71.82$ years, $S D=6.03)$. Investigating the concurrent relationships, we relied on the Big Five personality model and the Keyes's model of WB, which entails emotional well-being (EWB), psychological well-being (PWB), and social well-being (SoWB). We also considered the participants' background characteristics (age, gender, marital status and educational level), and their subjective health status in predicting the components of WB. The respondents filled-in a scale of subjective health, constructed for the purpose of the study, the Big Five Inventory and the Mental Health Continuum - Short Form. The demographic characteristics did not significantly contribute to any aspect of WB, whereas selfreported health significantly improved the prediction of EWB and PWB. The Big Five uniquely predicted all of the components of WB, over and above demographics and subjective health. Agreeableness was a significant single predictor across the components of WB. Higher levels of conscientiousness and lower levels of neuroticism contributed to EWB. Conscientiousness, extraversion, and openness predicted PWB, and openness predicted SoWB.
\end{abstract}

Keywords: elderly, personality, Big Five, subjective well-being, Keyes's model

\section{Osebnostne lastnosti kot napovedniki različnih vidikov subjektivnega blagostanja pri starejših odraslih}

\author{
Mojca Petrič ${ }^{1,2^{*}}$ in Maja Zupančič \\ ${ }^{1}$ Oddelek za psihologijo, Filozofska fakulteta, Univerza v Ljubljani, Slovenija \\ ${ }^{2}$ Oddelek za psihoterapijo, Psihiatrična bolnišnica Begunje, Slovenija
}

Povzetek: V raziskavi smo proučili sočasno napovedno vrednost osebnostnih potez za tri sestavine subjektivnega blagostanja pri normativnem vzorcu $(N=272 ; 70 \%$ žensk) starejših odraslih $(M=71,82$ let, $S D=6,03)$ v Sloveniji. Pri tem smo izhajali iz modela Velikih pet osebnostnih lastnosti ter Keyesovega celostnega modela subjektivnega blagostanja (SB), ki vključuje čustveno (ČB), psihološko (PB) in socialno blagostanje (SoB). V napovednih modelih SB smo najprej upoštevali demografske značilnosti udeležencev (spol, starost, zakonski stan, raven izobrazbe) in njihovo subjektivno oceno zdravja, potem pa dodali samoocene petih osebnostnih lastnosti. Uporabili smo Vprašalnik subjektivne ocene zdravja, ki smo ga oblikovali za namen raziskave, kratko obliko Kontinuuma duševnega zdravja ter Vprašalnik pet velikih faktorjev BFI. Demografske značilnosti niso značilno napovedovale sestavin SB, medtem ko je subjektivna ocena zdravja prirastno pojasnila značilen delež variance v ČB in PB. Sklop petih osebnostnih lastnosti je značilno izboljšal napoved, preko demografskih značilnosti in subjektivne ocene zdravja. Pri tem se je sprejemljivost povezovala z vsemi tremi sestavinami SB, štiri osebnostne lastnosti pa so se s posameznimi sestavinami SB povezovale razlikovalno. Visoka raven vestnosti in nizka raven nevroticizma sta pomembno napovedovali $\breve{C} B$, vestnost, ekstravertnost in odprtost so napovedovale PB, odprtost pa SoB.

Ključne besede: starejši odrasli, osebnost, Velikih pet, subjektivno blagostanje, Keyesov model blagostanja

\footnotetext{
"Naslov/Address: dr. Mojca Petrič, Department of Psychotherapy, Psychiatric Hospital Begunje, Begunje na Gorenjskem 55, 4275 Begunje, Slovenia, e-mail: mojca5ric@gmail.com
}

Članek je licenciran pod pogoji Creative Commons Attribution 4.0 International licence. (CC-BY licenca).

The article is licensed under a Creative Commons Attribution 4.0 International License (CC-BY license). 
Life expectancy of human populations has been steadily increasing over the past decades, with approximately $20 \%$ of the EU population recently representing the age group of elderly (65 years and above) (Eurostat, 2019). Likewise, $18.9 \%$ of the elderly have lately constituted the Slovene population (Statistical Office, 2017), with male-female ratio of $1: 1.32$ (Eurostat, 2019). These demographic trends in population aging present one of the key challenges for the countries involved, as the phenomena has important implications for policy-making in the area of pension, social and health security systems, labour market, etc. Although gerontologists and professionals in related fields have been emphasizing the significance of quality aging in terms of an active and healthy life-style for a half of century, the quality aging has become one of the central topics of research about 30 years ago, especially due to its connection to policyplanning of national social systems (Baltes \& Baltes, 1990). However, developmental research of quality aging is still underrepresented in the psychological literature, and remains particularly scarce in Slovenia.

Understanding the process of aging is also essential at the level of aging individuals in order to contribute to the quality of their life in the old age. Researchers proposed different models and theories of quality or successful aging. Rowe and Kahn's (1997) model is one of the best known and broadly applied. It emphasises an absence of physical illness and related limitations, maintenance of a high level of physical and mental activity, and active engagement in life. However, the model has been widely criticised in the academic community due to inferring a calculable high standard of successful ageing and excluding the presence of different medical conditions in late adulthood, as well as by its failure to capture a life course perspective (Dillaway \& Byrnes, 2009; Stowe \& Cooney, 2015). Contemporary conceptualizations of successful aging take into account age-related physical and psychological decline, but suggest effective ways of coping (e.g., the model of selective optimization with compensation; Baltes \& Baltes, 1990) or focus on subjectively perceived positive outcomes in the face of age-related losses, assessed by what is commonly referred to as subjective well-being (WB). In relation to successful aging, WB has gained lots of research interest over the recent years, especially in the United Kingdom and the United States (e.g., Jivraj et al., 2014).

There are different approaches to the conceptualization and measurement of WB. In the present study, we relied on the Keyes's comprehensive model of WB (also referred to as positive mental health) that captures three different, yet related components (Gallagher et al., 2009; Keyes, 2002, 2009): emotional WB (EWB), psychological WB (PWB) and social WB (SoWB). Specifically, we focused on plausible factors (background, subjectively perceived physical health, and personality) in predicting the components of WB among normative (relatively healthy and independent) Slovene elderly.

\section{Subjective well-being}

Abundant research considers subjective WB as life satisfaction - a global cognitive evaluation of one's life (e.g., DeNeve and Cooper, 1998; Diener, 2000, 2012; Steel et al.,
2008), whereas other authors distinguish between hedonic (pleasurable life) and eudaimonic WB (meaningful life). Hedonic WB, referred to as EWB by Keyes (2002), reflects experiences of positive affect, absence of negative affect, and satisfaction with life. In contrast, eudaimonic WB is primarily conceived as an outcome of engagement in meaningful activities and actualization of one's own potentials (Ryan \& Deci, 2001; Waterman, 1993). It is well represented by the model of psychological WB (PWB; Ryff, 1989), which involves autonomy, environmental mastery, personal growth, positive relations with others, purpose in life, and self-acceptance. Keyes (1998, 2002, 2009) included the Ryff's PWB model into his comprehensive conceptualization of WB, but further extended the eudaimonic WB to a wider interpersonal domain and introduced social WB (SoWB). SoWB indicates a degree to which people function well in their social world beyond close relationships; it includes evaluations of one's social integration and social contribution, social coherence (the quality, organization and functioning of the society), social actualization (society's potentials for social growth), and social acceptance (feeling comfortable with other members in the society).

A large body of research has addressed hedonic WB (predominantly life satisfaction) and provided evidence on its correlates (e.g., Diener et al., 1991; Diener et al., 2003; Gomez et al., 2009; Steel et al., 2008), but less is known how these variables relate to the aspects of eudaimonic WB (PWB and SoWB). The contribution of personality traits, for example, has been well recognised for some aspects of $\mathrm{WB}$, but mostly in age-heterogeneous adult samples, rarely including older adults over 75 years (e.g., Keyes et al., 2002), with few exceptions (e.g. Gomez et al., 2009; Kahlbaugh \& Huffman, 2017; Stephan, 2009). Therefore, we focused on the unique role of personality traits in explaining different components of WB specifically in late adulthood. There is namely scarce evidence that age may moderate the effect of traits on WB (e.g., Gomez et al., 2009; Stephan, 2009). Given that the elderly cope with different developmental tasks than younger individuals, it seems plausible to assume that some traits, such as extraversion, do not have the same role in the old adults' aspects of WB as compared to young or middleaged adults.

\section{Background characteristics, health status and subjective well-being}

Research across adulthood pointed out that background characteristics, such as age, gender, level of education, and marital status tend to have a rather small effect on WB (e.g., Diener et al., 2003; Hansen \& Slagsvold, 2012; Lamers et al., 2012; Snowden et al., 2010). The associations of WB with age and gender appear inconsistent across studies. A meta-analysis by Pinquart and Sörensen (2000) and findings of Keyes (1998, 2007; Keyes et al., 2002) suggest modest positive relationships of education with EWB, PWB, and SoWB. Married individuals report on somewhat higher levels of EWB and PWB than their single, divorced, and widowed peers (Mroczek \& Spiro, 2005; Shapiro \& Keyes, 2008), a result also found in elderly adults (Bennett, 2005; Mroczek $\&$ Spiro, 2005). No status difference was demonstrated for 
SoWB (Shapiro \& Keyes, 2008). Nevertheless, we included those background characteristics of the elderly in our analyses, but considered them in an initial block of variables, possibly explaining at least a small portion of individual differences in the components of WB.

In general, self-evaluations of physical health (subjective health) demonstrate stronger connections with EWB (or life satisfaction) than objective measures, such as reports by doctors, number of visits at medical centres, records of chronical illnesses, or other physical conditions (Binder \& Coad, 2013; Diener et al., 1999; Fagerström et al., 2007). The physical health-EWB relationships may be explained by EWB-to-health effects (higher levels of EWB contribute to better health), as well as by health-to-EWB effects (health influences EWB), with the latter estimated stronger than the former (Binder \& Coad, 2013). Furthermore, poor health elicits negative emotions and/or pain, and may prevent individuals from engagement in several pleasurable (or even necessary) everyday activities, spending leisure time in preferential ways, and investment into productive, subjectively meaningful endeavours; thus, health may indirectly or directly affect PWB (Ryan \& Deci, 2001). Yet, Ryff's (2013) overview suggests that individuals with higher levels of PWB are also more likely to exhibit greater care for their health and use more effective coping strategies to manage stress, which may protect from or at least delay development of illness.

As we collected data only at one time-point, we proposed that self-perceptions of better health among the elderly would predict higher levels of their EWB and PWB, over and above the background characteristics. Due to a lack of empirical foundation, we refrained from formulating a hypothesis on the relationship of subjective health with SoWB.

\section{The big five personality traits and subjective well-being}

Enduring personality predispositions (traits) appear among the most powerful factors influencing EWB or life satisfaction (e.g., DeNeve \& Cooper ,1998; Diener, 2000; Diener \& Lucas, 1999; Gomez et al., 2009; McCrae \& Costa, 1991; Steel et al., 2008). Abundant research in this area has relied on the Big Five model of personality traits. Extraversion and neuroticism have been demonstrated to play a central role in explaining individuals' perceptions of their life as pleasurable (Costa \& McCrae, 1980; DeNeve \& Cooper, 1998; Diener et al., 1999; Gomez et al., 2009; Steel et al., 2008), and have been suggested to affect EWB through biological and behavioural pathways (e.g., Ozer \& Benet-Martínez, 2006).

The neuro-biologically based behavioural activation system (Gray, 1990) is linked to extraversion and influences behavioural approach by indicating the presence of rewards through the promotion of positive affect, making extraverts more likely to attend to rewards and find them more enjoyable. The behavioural inhibition system (Gray, 1990) is related to neuroticism and regulates behavioural avoidance by signalling the presence of punishers through the endorsement of negative affect, making emotionally instable individuals more prone to attend to punishers, and avoid them (Elliot \& Thrash, 2002). Nevertheless, manifestations of traits may help create environments that influence EWB.
Extraverts spend more time socializing and tend to be happier in social situations (Pavot et al., 1990). They are also likely to form satisfying close relationships, whereas the opposite often holds for emotionally instable individuals, prone to negativity (e.g., Belsky et al., 2003).

However, it seems that the role of extraversion in attaining hedonic pleasure decreases over the adult years (Gomez et al., 2009), whereas neuroticism remains predictive (Lamers et al., 2012), or becomes more influential in late adulthood (Gomez et al., 2009). Several studies also revealed weak but significant associations of agreeableness and conscientiousness with EWB (DeNeve \& Cooper, 1998; Lucas, 2008; McCrae \& Costa, 1991; Steel et al., 2008; Zupančič \& Kavčič, 2017) though others suggested no connection (e.g., Gomez et al., 2009; Lamers et al., 2012). Given the mixed evidence on those relationships and no significant link of extraversion to EWB in late adulthood, we expected that the elderly with higher levels of neuroticism would report on lower levels of EWB.

With regard to PWB, Schmutte and Ryff (1997) proposed that basic emotional tendencies, captured by extraversion and neuroticism might influence feelings of self-acceptance and beliefs about one's capability to direct and manage everyday activities (environmental mastery), whereas agreeableness, conscientiousness, and openness might show instrumental links with autonomy, personal growth and positive interpersonal relationships. In middle-aged adults, they indeed found differential relationships of PWB with the Big Five. Energetic, assertive individuals, prone to experience positive emotions concurrently felt more pleased with themselves, in control of their environment, engaged in meaningful lives, and reported on more positive close relationships. The opposite was established for anxious, worry-some, moody, highly emotionally reactive individuals, who also reported on lower levels of autonomy. Based on the outcomes, Schmutte and Ryff further concluded that a responsible life-style of conscientious adults could have enabled them to reach all those attributes of PWB. Personal growth further demonstrated connections with extraversion and openness, suggesting that energy, imagination and curiosity may drive people at midlife to grow and improve themselves. Finally, agreeableness showed links with positive interpersonal relations, possibly because agreeable individuals surround themselves with warm and supportive others.

In a similar vein, Abbot et al. (2008) revealed significant relationships of extraversion in adolescence/emerging adulthood with PWB at midlife, whereas an increase in agreeableness, conscientiousness, and openness predicted subsequent PWB in university students (Zupančič \& Kavčič, 2017). Controlling for background characteristics and psychopathology, concurrent relations of extraversion and openness with PWB were also reported in a sample across the adult life span (Lamers et al., 2012). Relying on empirical evidence and theoretical considerations (Ryff, 1989), we expected higher levels of extraversion, agreeableness, conscientiousness, and openness to predict higher levels of PWB in our elderly sample.

Up to date, little research attention has been devoted to personality in relation to SoWB. Scant cross-sectional and longitudinal studies suggest associations of agreeableness and/or openness (Hill et al., 2012; Joshanloo \& Nosratabadi, 
2009; Lamers et al., 2012; Zupančič \& Kavčič, 2017) with SoWB, especially with evaluations of one's social value and functioning of the social world (Hill et al., 2012; Joshanloo et al., 2012). The pro-social tendencies of agreeable people may make them more liable to make sense of their life in a given community, apprise their social life, and less likely to criticize the society. Nevertheless, they are also prone to pliability and vulnerable to manipulation (Schmutte \& Ryff, 1997), which may make them unlikely to complain about the society, realize when the community members/institutions take advantage of them and/or the community does not function in a discernible way. Furthermore, individuals high in openness are more willing to accept new ideas, directions, perform new behaviours, or change habits (Lamers et al., 2012), which may enhance their coping with social tasks and successful responses to social challenges of life. In line with those considerations, but sparse empirical evidence, we proposed that more agreeable and open elderly adults would endorse higher levels of SoWB.

\section{The present study}

In sum, the first goal of this study was to examine the unique predictive value of the Big Five personality traits for the three components of WB in a sample of normative elderly Slovenes, over and beyond their background characteristics and subjective health. As for the second goal, we aimed to test the ability of each of the Big Five traits to differentially predict separate components of WB, i.e. EWB, PWB, and SoWB.

Drawing upon the aforementioned conceptualizations and empirical research, we formulated the following hypotheses: (H1) background characteristics of the elderly would contribute very little to the components of their WB; (H2) better self-perceived health would predict higher EWB and PWB, over and above the background characteristics; (H3) the Big Five would uniquely predict the components of WB, beyond subjective health; (H4) lower neuroticism would contribute to higher EWB, higher agreeableness and openness would relate to higher eudaimonic WB (PWB and SoWB), whereas higher conscientiousness would specifically predict higher PWB; given that we focused on late adulthood, we expected extraversion to positively associate with PWB.

\section{Method}

\section{Participants}

Participants were 272 relatively healthy, communitydwelling adults, aged from 65 to 91 years $(M=71.82$ years, $S D=6.03 ; 70 \%$ females), residing in different regions of Slovenia. Of the respondents, $59.9 \%$ were married or in a long-term relationship, $5.9 \%$ were divorced, $28.3 \%$ were widowed, $3.7 \%$ single (never married), and $2.2 \%$ of them did not report their marital status. With respect to educational level, 9.4\% had not finished eight years of compulsory school, $13.8 \%$ completed the compulsory school, $48.1 \%$ finished a lower/middle vocational or secondary school (2-, 3- or
4- years), $18.7 \%$ had a higher vocational education (tertiary) and $10 \%$ obtained a university degree (missing data for $1.5 \%$ of the respondents).

\section{Instruments}

Subjective health was measured by four items, based on previous research by several authors (e.g., Sargent-Cox et al., 2010; Staudinger et al., 1999; Teuscher, 2009). Using a five-point Likert-type scale, our participants rated their overall health ("How would you rate your overall health at the present time?") (1 - excellent, 5 - very bad) (reverse coded), compared their health to the health of their peers ("How would you rate your health, compared to most people of your age?") (1 - much worse, 5 - much better) and compared their current health to their health in the previous year ("Compared to 12 months ago, how would you rate your health now?") ( 1 - much better, 5 - much worse) (reverse coded). Another item referred to self-perceived everyday performance due to one's health ("Over the last month, how much did your health hamper your performance on everyday tasks or other daily activities?") (1 - not at all, 5 - I was not able to do anything by myself) (reverse coded). The confirmatory factor analysis of the four items revealed one factor (Petrič, 2015). The internal consistency of the scale in the present sample was .76.

The Big Five Personality Inventory (BFI; John et al., 1991) is a self-report instrument, designed to measure extraversion, agreeableness, conscientiousness, neuroticism and openness. It consists of 44 short phrases, which the participants rated along a 5-point Likert scale (1 - strongly disagree, 5 - strongly disagree). John and Srivastava (1999) supported the five-factor structure of the BFI and reported on good psychometric properties of the scales (internal consistency, test-retest reliability, and adequate convergent validity by correlations of the BFI scales with the NEO-FFI and the TDA scales). The exploratory factor analysis of the Slovene version of the BFI (Avsec \& Sočan, 2007) further suggested five factors interpretable in terms of the five basic personality dimensions, with satisfactory internal reliability of the scales. The five-factor structure of the BFI was also supported in our sample of elderly, but with some modifications -12 items were omitted due to low factor loadings or loadings on non-corresponding factors (Petrič, 2015). The internal consistency of the scales of the modified (reduced) BFI was acceptable in our sample, i.e., .67 for extraversion, .74 for conscientiousness, .61 for agreeableness, .73 for neuroticism and .77 for openness.

Mental Health Continuum - Short Form (MHC-SF; Keyes, 2009) consists of 14 items designed to assess the components of subjective well-being (WB) or positive mental health. Three items capture hedonic or EWB (happy, interested in life, and satisfied); six items characterize psychological aspects of eudaimonic WB or PWB, i.e., one item for each of the dimensions in Ryff's model (1989); five items depict social aspects of eudaimonic WB or SoWB - one item for each of the five dimensions of the Keyes's (1998) model of SoWB. The items are assessed on a six-point frequency scale, measuring how often the respondents experienced each of the indicators $(0-$ never, 5 - every day). The three-factor 
structure of the MHC-SF, as well as the reliability and validity of the three scales have been demonstrated with adolescent and adult samples in several countries (e.g., the Netherlands, South Africa, the USA) (Keyes, 2009). In Slovenia, two comprehensive analysis of the instrument were previously reported (Petrič, 2015; Zager Kocjan, 2016), supporting the construct validity of the three-factor structure and good internal reliability of the scales. One of them (Petrič, 2015) has been performed exclusively with a sample of elderly adults. Also, the alfa coefficients in the present sample were satisfactory (.82 for EWB, .80 for PWB and .71 for SoWB).

\section{Procedure}

We recruited the participants through organisations for elderly adults in Slovenia, such as centres of daily activities, societies for retired persons, cross-generational societies, and universities for the third life period. Additionally, we used a snowball sampling. All of the participants provided an informed written consent prior to taking part in the study. First, they responded to the demographic questions (age, gender, place of residence, marital status, and educational level). Then, they filled out self-report questionnaires (paper-pencil style) or were engaged in a structured, faceto-face interview, conducted by a psychologist or a trained "senior" psychology student. In the face-to-face interview, the interviewer was reading the questionnaire items aloud to the participants, while the rating scale was mounted in front of them. The questionnaires were administered in the same rank-order as presented in the Measures subsection. In a previous personality study with the Slovene elderly, no effect of style of application on the results of the Big Five Questionnaire was found (Caprara et al., 2012). The Ethics committee of the Department of Psychology, University of Ljubljana, Faculty of Arts, approved the study.

\section{Data analysis}

Preliminary analyses were performed to ensure the assumptions of normality, linearity, no multicollinearity, homoscedasticity, and independent errors were upheld. At the initial stage of analysis, we examined bivariate relationships between the key variables. Marital status and gender were coded as dichotomous variables $(0=\mathrm{married} / \mathrm{in}$ a partnership, $1=$ single across life/divorced/widowed; $0=$ male, $1=$ female) . Age and education were coded as ratio variables (in years). In order to test the unique predictive value of each block of predictors (demographics, subjective health, and personality traits), we performed a set of hierarchical regression analyses to predict EWB, PWB, and SoWB separately. The first block of predictors thus included the participants' gender, age, marital status, and their level of education. We entered the scale-scores on subjective health in the second step, and added the block of the Big Five in the third step.

\section{Results}

Table 1 displays means, standard deviations, and pairwise Pearson's correlation coefficients across the variables, and we only describe statistically significant associations next.

Considering the background variables, age negatively correlated with the components of WB, subjective health, and openness, while the level of neuroticism showed a modest positive association with the participants' age. Females scored somewhat lower for openness than males, years of completed education were negatively related to both neuroticism and conscientiousness (low correlations) and positively associated with openness (moderate correlations), while the marital status showed no relationship with any of the studied variables.

Table 1

Means, standard deviations and Pearson correlation coefficients between the key variables under study

\begin{tabular}{|c|c|c|c|c|c|c|c|c|c|c|c|}
\hline & $M$ & $S D$ & EWB & PWB & SWB & $\mathrm{E}$ & $\mathrm{A}$ & $\mathrm{C}$ & $\mathrm{N}$ & $\mathrm{O}$ & $\mathrm{SH}$ \\
\hline \multicolumn{12}{|l|}{ Subjective well-being } \\
\hline EWB & 3.33 & .99 & & & & & & & & & \\
\hline PWB & 3.75 & .80 & $.63^{* *}$ & & & & & & & & \\
\hline SWB & 2.58 & .98 & $.51^{* *}$ & $.59^{* *}$ & & & & & & & \\
\hline \multicolumn{12}{|l|}{ Personality traits } \\
\hline $\mathrm{E}$ & 3.78 & .86 & $.27^{* *}$ & $.34^{* *}$ & $.20^{* *}$ & & & & & & \\
\hline A & 4.01 & .63 & $.27^{* *}$ & $.34^{* *}$ & $.25^{* *}$ & $.18^{* *}$ & & & & & \\
\hline $\mathrm{C}$ & 4.13 & .56 & $.22^{* *}$ & $.37^{* *}$ & $.22^{* *}$ & $.23^{* *}$ & $.24^{* *}$ & & & & \\
\hline $\mathrm{N}$ & 2.67 & .72 & $-.35^{* *}$ & $-.28^{* *}$ & $-.21^{* *}$ & $-.41^{* *}$ & $-.19^{* *}$ & $-.14^{*}$ & & & \\
\hline $\mathrm{O}$ & 3.51 & .66 & $.26^{* *}$ & $.38^{* *}$ & $.27^{* *}$ & $.17^{* *}$ & $.20^{* *}$ & $.28^{* *}$ & -.08 & & \\
\hline Subjective health $\mathrm{SH}$ & 3.25 & .71 & $.48^{* *}$ & $.33^{* *}$ & $.22^{* *}$ & $.22^{* *}$ & .12 & .05 & $-.29^{* *}$ & $.26^{* *}$ & \\
\hline \multicolumn{12}{|l|}{ Demographics } \\
\hline Age & 71.82 & 6.03 & $-.14^{*}$ & $-.15^{*}$ & $-.14^{*}$ & .03 & .01 & .07 & $.15^{*}$ & $-.22^{* *}$ & $-.24^{* *}$ \\
\hline Education & 11.38 & 2.74 & .12 & .03 & .07 & .06 & -.08 & $-.14^{*}$ & $-.19^{* *}$ & $.34^{* *}$ & $.23^{* *}$ \\
\hline Gender & & & -.08 & .07 & -.03 & .01 & .10 & .00 & -.01 & $-.13^{*}$ & .02 \\
\hline Marital status & & & -.03 & .02 & -.01 & -.01 & -.03 & -.09 & .03 & -.10 & .02 \\
\hline
\end{tabular}

Notes. $\mathrm{EWB}=$ emotional well-being, $\mathrm{PWB}=$ psychological well-being, $\mathrm{SoWB}=$ social well-being, $\mathrm{SH}=$ subjective health, $\mathrm{E}=$ extraversion, $\mathrm{A}=$ agreeableness, $\mathrm{C}=$ conscientiousness, $\mathrm{N}=$ neuroticism, $\mathrm{O}=$ openness, Education = years in education. ${ }^{* *} p<.01 ;{ }^{*} p<.05$ 
Table 2

Summary of the hierarchical regression analyses with demographics, subjective health, and personality traits predicting the three components of well-being

\begin{tabular}{|c|c|c|c|c|c|c|c|c|c|}
\hline & \multicolumn{3}{|c|}{ Emotional well-being } & \multicolumn{3}{|c|}{ Psychological well-being } & \multicolumn{3}{|c|}{ Social well-being } \\
\hline & Step1 & Step2 & Step3 & Step1 & Step2 & Step3 & Step 1 & Step2 & Step3 \\
\hline GEN & -.08 & -.09 & -.11 & .05 & .05 & .04 & -.05 & -.05 & -.06 \\
\hline MS & .04 & .00 & .04 & .03 & .01 & .06 & .04 & .03 & .06 \\
\hline AGE & -.13 & -.04 & -.05 & $-.16^{*}$ & -.10 & -.11 & $-.15^{*}$ & -.11 & -.11 \\
\hline EDU & .06 & -.02 & -.03 & -.02 & -.08 & -.11 & .01 & -.02 & -.04 \\
\hline $\mathrm{SH}$ & & $.48^{* * *}$ & $.38^{* * *}$ & & $.32^{* * *}$ & $.17^{* *}$ & & $.20^{* *}$ & .10 \\
\hline $\mathrm{E}$ & & & .06 & & & $.16^{* *}$ & & & .07 \\
\hline A & & & $.16^{* *}$ & & & $.16^{* *}$ & & & $.16^{* *}$ \\
\hline $\mathrm{C}$ & & & $.12^{*}$ & & & $.20^{* * *}$ & & & .11 \\
\hline $\mathrm{N}$ & & & $-.17^{* *}$ & & & -.11 & & & -.09 \\
\hline $\mathrm{O}$ & & & .06 & & & $.23^{* * *}$ & & & $.15^{* *}$ \\
\hline$\Delta R^{2}$ & .03 & .21 & .11 & .03 & .09 & .25 & .02 & .04 & .11 \\
\hline $\mathrm{F}$ & & & & & & & & & \\
\hline$\Delta F$ & 2.18 & $72.66^{* * *}$ & $9.10^{* * *}$ & 1.91 & $27.86^{* * *}$ & $21.16^{* * *}$ & 1.56 & $10.19^{* *}$ & $7.21^{* * *}$ \\
\hline$d f$ & 4,267 & 1,266 & 5,261 & 4,267 & 1,266 & 5,261 & 4,267 & 1,266 & 5,261 \\
\hline$\sum R^{2}$ & .03 & .24 & .35 & .03 & .12 & .37 & .02 & .06 & .17 \\
\hline$\sum R^{2}($ adj $)$ & .02 & .22 & .33 & .01 & .10 & .35 & .01 & .04 & .14 \\
\hline$F$ & 2.18 & $16.74^{* * *}$ & $14.19^{* * *}$ & 1.91 & $7.25^{* * *}$ & $15.58^{* * *}$ & 1.56 & $3.33^{* *}$ & $5.46^{* * *}$ \\
\hline$d f$ & 4,267 & 5,266 & 10,261 & 4,267 & 5,266 & 10,261 & 4,267 & 5,266 & 10,261 \\
\hline
\end{tabular}

Note. Standardized $\beta$ coefficients are presented in the upper part of the table for each block of predictors. GEN $=$ gender, MS $=$ marital status, $\mathrm{EDU}=$ years in education, $\mathrm{SH}=$ subjective health, $\mathrm{E}=$ extraversion, $\mathrm{A}=$ agreeableness, $\mathrm{C}=$ conscientiousness, $\mathrm{N}=$ neuroticism, $\mathrm{O}=$ openness. ${ }^{* * *} p<.001 ;{ }^{* *} p<.01 ;{ }^{*} p<.05$

The correlations of subjective health and personality traits with each of the three components of WB were positive (except for neuroticism), most of them were modest. More notably, the participants reporting on better health scored higher in PWB and EWB, whereas those with lower levels of neuroticism, and higher levels of the remaining traits reported on more meaningful life (PWB); more emotionally stable (neuroticism reversed) elderly also exhibited higher levels of EWB.

Subjective health was modestly connected to extraversion, openness (both positively), and neuroticism (negatively). The inter-correlations among the components of WB were relatively high, as expected (e.g., Gallagher et al. 2009). The inter-correlations among the five personality traits were modest, except for a moderate negative association of neuroticism with extraversion and no association of neuroticism with openness.

Table 2 displays the summary of the hierarchical Regression Analyses. The block of background variables accounted for non-significant $3 \%$ of the variance explained in both EWB and PWB, and 2\% in SoWB. Adding the data on subjective health statistically significantly improved the variance explained by $21 \%$ (EWB), 9\% (PWB) and 4\% (SoWB). More positive self-perceptions of health predicted higher levels of WB. The block of personality traits further provided a statistically significant increment of the variance explained in the components of $\mathrm{WB}$, over and beyond the demographics characteristics and subjective health. The Big Five uniquely accounted for $11 \%$ of the variance explained in both EWB and SoWB, and $25 \%$ of the variance in PWB.

Among single predictors of the components of WB in the last step of the analyses, none of the background characteristics of the elderly was statistically significant; higher levels of subjective health predicted higher levels of both EWB and PWB, and we found differential predictive relations of the Big Five with the three components of WB. Higher levels of both agreeableness and conscientiousness, as well as lower levels of neuroticism statistically significantly contributed to EWB, higher levels of extraversion, agreeableness, conscientiousness, and openness predicted greater PWB, whereas higher scores in both agreeableness and openness forecasted higher levels of SoWB. In sum, agreeableness significantly contributed to the variance explained across the components of subjective WB, while the remaining personality traits had a differential effect on those components.

\section{Discussion}

The goal of the present inquiry was to examine the unique predictive relations of the Big Five personality traits with subjective well-being (WB) or positive mental health in elderly adults, over and beyond their background characteristics and self-assessments of physical health, which appears 
particularly relevant for WB in late adulthood. Although the contribution of personality traits to hedonic WB across adulthood has been well recognised, less attention has been devoted to the potential differential role of personality traits on distinctive components of WB, i.e. emotional (EWB), psychological (PWB) and social (SoWB) well-being in elderly adults.

In line with previous studies (Bennett, 2005; Diener \& Suh, 1997; Hansen \& Slagsvold, 2012; Keyes, 2007; Shapiro \& Keyes, 2008) and our hypothesis (H1), age, gender, educational level, and marital status contributed very little to the three components of WB in the Slovene sample of normative elderly. As hypothesized (H2), subjective health improved the prediction of all aspects of WB, most notably EWB (by 21\%) as compared to PWB and SoWB (improvement by $9 \%$ and $4 \%$, respectively). Whereas the relationship between EWB and subjective physical health has been wellestablished (Binder \& Coad, 2013; Borg et al., 2005; Okun et al., 1984), less is known about the associations of health with eudaimonic aspects of WB (but see Ryff, 2013). We presume that individuals who assess their physical health more favourably tend to engage in different complex, productive and/or social activities aimed at achieving personally relevant long-term goals more readily, which may promote their perceptions of leading a meaningful life (PWB), as well as positive evaluations of their embedment into the social life and appraisals of their broader society (SoWB).

In support to our predictions (H3), the Big Five personality traits uniquely explained notable portions of variance in each of the three components of WB, with a greater unique contribution of the traits to PWB (25\%) than EWB and SoWB $(11 \%)$. The results further suggested differential relationships of the Big Five with the components of WB in our sample of normative elderly.

As expected (H4), extraversion predicted PWB, but not EWB. While the trait has been, along with neuroticism, considered to play an important role in EWB (Costa \& McCrae, 1980; Diener et al., 1999; Steel et al., 2008), the effect of extraversion may be moderated by adults' age (Gomez et al., 2009) and culture (Vittersø 2001). Hence, a propensity towards positive emotionality, expressiveness, sociability, and assertiveness seems likely to have a minor role in evaluations of hedonic pleasure among mid and old adults, or in cultures not stressing the significance of emotional expressiveness. However, higher levels of extraversion seem to contribute to PWB across different age periods (Lamers et al., 2012; Schmutte \& Ryff, 1997; Zupančič \& Kavčič, 2017). With respect to our elderly participants, we assume that due to their proneness toward positivity, gregariousness, outgoingness, activity and self-assertion, those higher in extraversion may hold more positive attitudes towards themselves (self-acceptance), maintain more satisfying interpersonal relationships with important others, render greater sense of coming to terms with the purpose of their past and present life, participate more actively in creating their environment (concordant with the activity theory; Lemon et al., 1972), and take more advantages of environmental opportunities (environmental mastery).

In contrast to extraversion, neuroticism was the only trait predictor of EWB, but did not predict other components of WB in our sample. The elderly scoring higher for anxiety, moodiness, fear, depression and irritability also reported on lower levels of happiness, interest in life and satisfaction. It appears in line with $\mathrm{H} 4$, derived from previous research outcomes (DeNeve \& Cooper, 1998; Lamers et al., 2012; Steel et al., 2008; Zupančič \& Kavčič, 2017), particularly in late adulthood (Gomez et al., 2009). As several authors suggested (e.g., Lamers et al. 2012; Ozer \& Benet-Martínez, 2006; Steel et al., 2008), the neuroticism-EWB relationships may be explained through several mechanisms. The biological pathways may reflect individual differences in BIS, promoting behavioural inhibition and avoidance of danger/ novelty (Gray, 1990), which is associated with negative affect (primarily anxiety) and results in low levels of pleasure. Behaviourally, less stable individuals also tend to engage in less favourable types of transactions with their environments (see Caspi, 1998). For example, due to their sensitivity and attentiveness to negative stimuli (Elliot \& Thrash, 2002), they are more likely to find them and thus, perceive and interpret their experiences more pessimistically, respond to others in a less favourable way (the reactive type of transaction), and elicit more negativity in people around them (the evocative type), all of which could make them less happy.

In partial discordance to $\mathrm{H} 4$, agreeableness predicted all three components of WB. Nevertheless, caution is needed not to overstate the strength of those relationships as agreeable individuals tend toward conformity, compliance, and pliability, which may make them more likely to feel, or at least to report, on enhanced levels of contentment with several aspects of their life (Schmutte \& Ryff, 1997). This turned out to be particularly the case with Slovene elderly adults (Caprara et al., 2012). Keeping this in mind, the results of our study indicate that more kind, friendly, co-operative, helpful, emphatically responsive, trustworthy and forgiving older adults tended to endorse higher levels of happiness, interest in life and satisfaction (EWB), as well as thriving in their private and social life (PWB and SoWB) than their peers who evaluated themselves lower in agreeableness. Compared to extraversion, the significance of agreeableness in late adulthood, particularly with respect to EWB, could be attributed to changing social goals with age as proposed by Carstensen (Carstensen et al., 1999) in her socioemotional selectivity theory. Over young adulthood, the acquisition of information and development or maintenance of self-concept is important. Young people hence tend to create broader social networks. In this respect, extraverts may benefit from their inclination toward social engagement and enjoyment in social situations for it increases the likelihood of establishing a wider-range of social contacts, which augment their level of EWB. However, more meaningful goals gain in vitality with increasing age. Individuals thus tend to become more selective, they systematically narrow their social networks and invest more in rewarding (mutually warm, intimate, trusting, reliable, understanding) relationships. Since older adults are likely to put a greater value on such kind of relationships, agreeableness may become more central in attaining hedonic pleasure (EWB) than extraversion.

Agreeableness has further shown associations with eudaimonic aspects of WB across different age periods (Lamers et al., 2012; Schmutte and Ryff, 1997; Zupančič \& Kavčič, 2017) and uniquely predicted PWB, as well as SoWB in our elderly sample. The respective relationships may be 
explained instrumentally (McCrae \& Costa, 1991; Ozer \& Benet-Martínez, 2006). In their private lives, individuals may achieve especially satisfying interpersonal ties through their sympathetic, caring, friendly, good-mannered and trusting tendencies (e.g., Schmutte \& Ryff, 1997). Moreover, through the mutually rewarding and supportive close relationships they may enhance their appraisals of self and accomplish a sense of competence in mastering their life (PWB). Behavioural tendencies of agreeable people may also provide instrumental avenues toward achieving satisfaction in their public life as reflected in SoWB (Zupančič \& Kavčič, 2017). Agreeable behaviour may, for example, contribute to one's cooperative functioning in the community life, holding favourable views of human nature and feeling comfortable with other people, considering self as a part of society, recognizing potentials of the society to develop and opportunities the community or society offers to its members. Prosocial behaviour and views may further increase the likelihood of agreeable people of receiving support from the community, which could in turn enhance their evaluations of performing well in social life.

With regard to other significant associations in our elderly sample, conscientiousness predicted EWB and PWB, whereas openness influenced PWB and SoWB. A hypothesis of the instrumental personality-WB linkage offers several possibilities through those traits may relate to WB outcomes. More rule-abiding, systematic, organized, achievementstriving, persistent and responsible (i.e., conscientious) old adults remain healthier through engagement in variety of positive health-related behaviours, and selecting healthier environments and friendships (e.g., Friedman \& Kern, 2014). Thus, they may experience more pleasant and less unpleasant emotions in daily life (reflected in EWB). They may likewise deem a more meaningful private life (PWB) because they tend to develop effective coping with difficulties (Ryff, 2013), high levels of social competence and productivity (McCrae \& Löckenhoff, 2014; Roberts et al., 2013), which may enhance a stronger sense of mastery of one's own life and environments. As conscientiousness is associated with goal-setting (Roberts et al., 2013) and activities aimed at achieving personally relevant long-term goals are related to PWB (Vittersø, 2001; Waterman, 1993), motivational aspects of functioning may provide another avenue to PWB in the old age.

In addition to studies reporting on the role of openness in PWB (Lamers et al., 2012; Stephan, 2009; Zupančič \& Kavčič, 2017) and SoWB (Hill et al., 2012; Joshanloo \& Nosratabadi, 2009; Joshanloo et al., 2012), we revealed predictive validity of the trait for PWB and SoWB in the elderly sample. The openness-PWB relationship in late adulthood was explained by Stephan (2009), who suggested that openness facilitates the development of an active post-retirement style. Individuals prone to seek out and enjoy new experiences, manifested in intellectual curiosity, active exploration, and open-mindedness more likely engage in various intellectual, cultural or physical activities, which satisfy their need for personal growth and development, and hence, promote PWB. By means of pursuing non-conformist, novel experiences and activities, willingness to expand one's horizons and accept novel ideas, people may also enjoy greater self-understanding (Schmutte \& Ryff, 1997) and develop a stronger sense of purpose in life when construing their life reviews in the old age. Likewise, curiosity and broad-mindedness in the elderly may facilitate better understanding of what is happening in their social world, acknowledgement of their embeddedness in a community, and recognizing themselves as potential beneficiaries of social growth (Zupančič \& Kavčič, 2017), i.e., SoWB.

Taken together, our study pointed out that four of the Big Five personality traits uniquely contribute to the components of WB in a sample of elderly differentially, whereas agreeableness plays a positive role across the components. Precisely, neuroticism relates to EWB, extraversion to PWB, conscientiousness to both EWB and PWB, and openness to eudaimonic WB (PWB and SoWB).

\section{Limitations and future prospects}

There are several shortcomings to this study. It was based on self-reports and thus, might have been subject to a single-informant bias, which tends to overestimate the associations due to the shared method variance. Crossinformant approaches, combining self-, spouse- and/or adult child report on elderly adults' WB, health, and personality or other multi-method approaches (e.g., objective measures of physical health and psychophysiological personality data) are recommended (Diener, 2012). Our sample also included independent, relatively healthy and rather young elderly adults. Hence, caution is needed against over-generalization of the outcomes across other groups of elderly, such as those residing in homes for the elderly, or those with physical and/ or mental disabilities.

Due to the cross-sectional and correlational nature of our study, we cannot draw conclusions about the directionality of the predictive relations. WB, for example, can affect individuals' health (e.g., Diener \& Chan, 2011; Ryff, 2013), not just the other way around. A cross-lagged panel design using longitudinal data, is henceforth needed. A fine-grained analyses considering lower-order components of EWB, PWB, and SoWB by using the full MHC form and a personality questionnaire providing trait scores at the facet level (e.g., BFQ; Caprara et al., 2012) would further offer a more comprehensive explanation of joint effects of personality, subjective health, and background characteristics on the components of WB.

Nonetheless, we believe that our findings add to the extant knowledge on the contribution of personality to WB by analysing the unique effects of the Big Five specifically in late adulthood, in particular among the elderly in Slovenia who are rarely represented in the psychological literature. The results of our study suggest that the traits of agreeableness, openness and conscientiousness are important resources of WB in the elderly, specifically of those aspects that have been rather neglected in research, namely PWB and SoWB. Since developmental needs and tasks in late adulthood include generativity, social relationships, and active life styles (e.g., Lemon et al., 1972; Rowe \& Kahn, 1997), the aspects of WB that refer to functioning in the social world (SoWB), engagement in meaningful activities and actualization of one's own potentials (PWB) are at least as important indicators of successful aging as EWB. 


\section{Acknowledgment}

This work was supported by grants of Slovene Research Agency \# P5-0062 (Applied developmental psychology).

\section{References}

Abbott, R. A., Croudace, T. J., Ploubidis, G. B., Kuh, D., Wadsworth, M. E. J., Richards, M., \& Huppert, F. A. (2008). The relationship between early personality and midlife psychological well-being: Evidence from a UK birth cohort study. Social Psychiatry and Psychiatric Epidemiology, 43(9), 679-687.

Avsec, A., \& Sočan, G. (2007). Vprašalnik petih velikih faktorjev BFI [The Big Five Inventory BFI]. In A. Avsec (Ed.), Psihodiagnostika osebnosti [Psychodiagnostics of personality] (pp. 171-178). Department of Psychology, University of Ljubljana.

Baltes, P. B., \& Baltes, M. M. (1990). Psychological perspectives on successful aging: The model of selective optimization with compensation. In P. B. Baltes \& M. M. Baltes (Eds.), Successful aging: Perspectives from the behavioral sciences (pp. 1-34). Cambridge University Press.

Belsky, J., Jaffee, S. R., Caspi, A., Moffitt, T., \& Silva, P. A. (2003). Intergenerational relationships in young adulthood and their life course, mental health, and personality correlates. Journal of Family Psychology, 17(4), 460-471.

Bennett, K. M. (2005). Psychological wellbeing in later life: The longitudinal effects of marriage, widowhood and marital status change. International Journal of Geriatric Psychiatry, 20(3), 280-284.

Binder, M., \& Coad, A. (2013). »I'm afraid I have bad news for you...«: Estimating the impact of different health impairments on subjective well-being. Social Science \& Medicine, 87, 55-167.

Borg, C., Hallberg, I. R., \& Blomquist, K. (2005). Life satisfaction among older people $(65+)$ with reduced self-care capacity: The relationship to social, health and financial aspects. Journal of Clinical Nursing, 15(5), 607-618.

Caprara, G. V., Barbaranelli, C., Borgogni, L., Bucik, V., Boben, D., Hruševar-Bobek, B., Zupančič M., \& Horvat, M. (2012). Model »velikih pet«: Pripomočki za merjenje strukture osebnosti: Priročnik [The Big Five Model: Questionnaires to assess personality structure: Assessment manual]. Center za psihodiagnostična sredstva.

Carstensen, L. L., Isaacowitz, D. M., \& Charles, S. T. (1999). Taking time seriously: A theory of socioemotional selectivity. American Psychologist, 54(3), 165-181.

Caspi, A. (1998). Personality development across the life course. In W. Damon \& N. Eisenberg (Eds.), Handbook of child psychology: Vol. 3. Social, emotional, and personality development (pp. 311-388). Wiley.

Costa, P. T., Jr., \& McCrae, R. R. (1980). Influence of extraversion and neuroticism on subjective well-being: Happy and unhappy people. Journal of Personality and Social Psychology, 38(4), 668-678.
DeNeve, K. M., \& Cooper, H. (1998). The happy personality: A meta-analysis of 137 personality traits and subjective well-being. Psychological Bulletin, 124, 197-229.

Diener, E. (2000). Subjective well-being: The science of happiness and a proposal for a national index. American Psychologist, 55(1), 34-43.

Diener, E. (2012). New findings and future directions for subjective well-being research. American Psychologist, 67, 590-597.

Diener, E., \& Chan, M. Y. (2011). Happy people live longer: Subjective well-being contributes to health and longevity. Applied Psychology: Health and Well-being, 3(1), 1-43.

Diener, E., \& Lucas, R. E. (1999). Personality and subjective well-being. In D. Kahneman, E. Diener, \& N. Schwarz (Eds.), Wellbeing: The foundations of hedonic psychology (pp. 213-229). Russell Sage Foundation.

Diener, E., Oishi, S., \& Lucas, R. E. (2003). Personality, culture, and subjective well-being: Emotional and cognitive evaluation of life. Annual Review of Psychology, 54, 403-425.

Diener, E., \& Suh, E. M. (1997). Measuring quality of life: Economic, social, and subjective indicators. Social Indicators Research, 40(1-2), 189-216.

Diener, E., Suh, E. M., Lucas, R. E., \& Smith, H. E. (1999). Subjective well-being: Three decades of progress. Psychological Bulletin, 125, 276-302.

Dillaway, H. E., \& Byrnes, M. (2009). Reconsidering successful aging: A call for renewed and expanded academic critiques and conceptualizations. Journal of Applied Gerontology, 28(6), 702-722.

Elliot, A. J., \& Thrash, T. M. (2002). Approach-avoidance motivation in personality: Approach and avoidance temperaments and goals. Journal of Personality and Social Psychology, 82(5), 804-818.

Eurostat. (2019). Ageing Europe. Looking at the lives of older people in EU. https://www.age-platform.eu/publications/ ageing-europe-looking-lives-older-people-eu-eurostat2019-report

Fagerström, C., Borg, C., Balducci, C., Burholt, V., Wenger, C. G., Ferring, D., Weber, G., Holst, G., \& Hallberg, I. R. (2007). Life satisfaction and associated factors among people aged 60 years and above in six European countries. Applied Research in Quality of Life, 2(1), 33-50.

Friedman, H. S., \& Kern, M. L. (2014). Personality, wellbeing, and health. Annual Review of Psychology, 65, 719-742.

Gallagher, M. W., Lopez, S. J., \& Preacher, K. J. (2009). The hierarchical structure of well-being. Journal of Personality, 77, 1025-1049.

Gomez, V., Krings, F., Baugarter, A., \& Grob, A. (2009). The influence of personality and life events on subjective well-being from a life span perspective. Journal of Research in Personality, 43, 345-354.

Gray, J. A. (1990). Brain systems that mediate both emotion and cognition. Cognition \& Emotion, 4(3), 269-288.

Hansen, T., \& Slagsvold, B. (2012). The age and subjective well-being paradox revisited: A multidimensional perspective. Norsk Epidemiologi, 22(2), 187-195. 
Hill, P. L., Turiano, N. A., Mroczek, D. K., \& Roberts, B. W. (2012). Examining concurrent and longitudinal relations between personality traits and social well-being in adulthood. Social Psychological and Personality Science, 3(6), 698-705.

Jivraj, S., Nazroo, J., Vanhoutte, B., \& Chandola, T. (2014). Aging and subjective well-being in later life. Journals of Gerontology Series B: Psychological Sciences and Social Sciences, 69(6), 930-941.

John, O. P., Donahue, E. M., \& Kentle, R. L. (1991). The Big Five Inventory--Versions $4 a$ and 54. University of California, Berkeley, Institute of Personality and Social Research.

John, O. P., \& Srivastava, S. (1999). The Big-Five trait taxonomy: History, measurement, and theoretical perspectives. In L. A. Pervin \& O. P. John (Eds.), Handbook of personality: Theory and research (pp. 102138). Guilford Press.

Joshanloo, M., \& Nosratabadi, M. (2009). Levels of mental health continuum and personality traits. Social Indicators Research, 90(2), 211-224.

Joshanloo, M., Rastegar, P., \& Bakhshi, A. (2012). The Big Five personality domains as predictors of social wellbeing in Iranian university students. Journal of Social and Personal Relationships, 29(5), 639-660.

Kahlbaugh, P., \& Huffman, L. (2017). Personality, emotional qualities of leisure, and subjective well-being in the elderly. The International Journal of Aging and Human Development, 85(2), 164-184.

Keyes, C. L. M. (1998). Social well-being. Social Psychology Quarterly, 61, 121-140.

Keyes, C. L. M. (2002). The Mental Health Continuum: From languishing to flourishing in life. Journal of Health and Social Behavior, 43, 207-222.

Keyes, C. L. M. (2007). Promoting and protecting mental health as flourishing: A complementary strategy for improving national mental health. American Psychologist, 62(2), 95-108.

Keyes, C. L. M. (2009). Brief description of the Mental Health Continuum Short Form (MHC-SF). https://www.aacu. org/sites/default/files/MHC-SFEnglish.pdf

Keyes, C. L. M., Shmotkin, D., \& Ryff, C. D. (2002). Optimizing well-being: The empirical encounter of two traditions. Journal of Personality and Social Psychology, 82(6), 1007-1022.

Lamers, S. M. A., Glas, C. A. W., Westerhof, G. J., \& Bohlmeijer, E. T. (2012). Longitudinal evaluation of the Mental Health Continuum-Short Form (MHC$\mathrm{SF}$ ): Measurement invariance across demographics, physical illness and mental illness. European Journal of Psychological Assessment, 28(4), 290-296.

Lemon, B. W., Bengtson, V. L., \& Peterson, J. A. (1972). An exploration of the activity theory of aging: Activity types and life satisfaction among in-movers to a retirement community. Journal of Gerontology, 27(4), 511-523.

Lucas, R. E. (2008). Personality and subjective well-being. In R. J. Larsen \& M. Eid (Eds.), The science of subjective well-being (pp. 171-194). Guilford Press.
McCrae, R. R., \& Costa, P. T., Jr. (1991). Adding liebe und arbeit: The full five-factor model and well-being. Personality and Social Psychology Bulletin, 17(2), 227-232.

McCrae, R. R., \& Löckenhoff, C. E. (2014). Self-regulation and the five-factor model of personality traits. In R. H. Hoyle (Ed.), Handbook of personality and self-regulation (pp.145-168). Wiley Blackwell.

Mroczek, D. K., \& Spiro III, A. (2005). Change in life satisfaction during adulthood: Findings from the Veterans affairs normative aging study. Journal of Personality and Social Psychology, 88(1), 189-202.

Okun, M. A., Stock, W. A., Haring, M. J., \& Witter, R. A. (1984). Health and subjective well-being: A metaanalysis. The International Journal of Aging and Human Development, 19(2), 111-132.

Ozer, D. J., \& Benet-Martinez, V. (2006). Personality and the prediction of consequential outcomes. Annual Review of Psychology, 57, 401-421.

Pavot, W., Diener, E., \& Fujita, F. (1990). Extraversion and happiness. Personality and Individual Differences, 11, 1299-1306.

Petrič, M. (2015). Napovedniki Keyesovega modela duševnega zdravja pri starostnikih [Predictors of the Keyes's model of mental health in elderly] [Unpublished doctoral dissertation]. University of Ljubljana.

Pinquart, M., \& Sörensen, S. (2000). Influences of socioeconomic status, social network, and competence on subjective well-being in later life: A meta-analysis. Psychology of Aging, 15(2), 187-224.

Roberts, B. W., Jackson, J. J., Fayard, J. V., Edmonds, G., \& Meints, J. (2013). Conscientiousness. In M. R. Leary \& R. H. Hoyle (Eds.), Handbook of individual differences in social behavior (pp. 369-381). The Guilford Press.

Rowe, J. W., \& Kahn, R. L. (1997). Successful aging. The Gerontologist, 37(4), 433-440.

Ryan, R. M., \& Deci, E. L. (2001). On happiness and human potentials: A review of research on hedonic and eudaimonic well-being. Annual Review of Psychology, 52, 141-166.

Ryff, C. D. (1989). Happiness is everything, or is it? Explorations on the meaning of eudaimonic well-being. Journal of Personality and Social Psychology, 57, 1069-1081.

Ryff, C. D. (2013). Eudaimonic well-being and health: Mapping consequences of self-realization. In A. S. Waterman (Ed.), The best within us: Positive psychology perspectives on eudaemonia (pp. 77-98). American Psychological Association.

Sargent-Cox, K. A., Anstey, K. J., \& Luszcz, M. A. (2010). Patterns of longitudinal change in older adults' selfrated health: The effect of the point of reference. Health Psychology, 29(2), 143-152.

Schmutte, P. S., \& Ryff, C. D. (1997). Personality and wellbeing: Reexamining methods and meanings. Journal of Personality and Social Psychology, 73(3), 549-559.

Shapiro, A., \& Keyes, C. L. M. (2008). Marital status and social well-being: Are the married always better off? Social Indicators Research, 88(2), 329-346. 
Snowden, M., Dhingra, S. S., Keyes, C. L. M., \& Anderson, L. A. (2010). Changes in mental well-being in the transition to late life: Findings from MIDUS I and II. American Journal of Public Health, 100(12), 2385-2388.

Statistical Office. (2017). Število in sestava prebivalstva [Population structure]. http://www.stat. si/StatWeb/Field/Index/104

Staudinger, U. M., Fleeson, W., \& Baltes, P. B. (1999). Predictors of subjective physical health and global wellbeing: Similarities and differences between the United States and Germany. Journal of Personality and Social Psychology, 76(2), 305-319.

Steel, P., Schmidt, J., \& Shultz, J. (2008). Refining the relationship between personality and subjective wellbeing. Psychological Bulletin, 123, 138-161.

Stephan, Y. (2009). Openness to experience and active older adults' life satisfaction: A trait and facet-level analysis. Personality and Individual Differences, 47(6), 637-641.

Stowe, J. D., \& Cooney, T. M. (2015). Examining Rowe and Kahn's concept of successful aging: Importance of taking a life course perspective. The Gerontologist, 55 (1), 43-50.

Teuscher, U. (2009). Subjective age bias: A motivational and information processing approach. International Journal of Behavioral Development, 33(1), 22-31.

Vittersǿ, J. (2001). Personality traits and subjective wellbeing: Emotional stability, not extraversion, is probably the important predictor. Personality and Individual Differences, 31(6), 903-914.

Waterman, A. S. (1993). Two conceptions of happiness: Contrasts of personal expressiveness (eudaimonia) and hedonic enjoyment. Journal of Personality and Social Psychology, 64, 678-691.

Zager Kocjan, G. (2016). Engagement, passion, and flow among employees: A theoretical and empiricaldistinction. [Unpublished doctoral dissertation]. University of Ljubljana.

Zupančič, M., \& Kavčič, T. (2017). Personality, life events, and three components of subsequent subjective wellbeing in female university students. Social Inquiry into Well-Being, 3(1), 1-14. 